\title{
The Government's Role in the Development of Yendi Beach Tourism Destinations in Biak Numfor Regency
}

\author{
Djamil Hasyim ${ }^{1}$, Amiruddin Gunawan ${ }^{2}$, Moh Sudi $^{3}$, Delly Mustafa ${ }^{4}$, Rijal ${ }^{5}$ \\ Institut Ilmu Sosial dan Ilmu Politik (IISIP) YAPIS Biak \\ Universitas Pejuang Republik Indonesia (UPRI) Makassar \\ E-mail: djamilhasim@iyb.ac.id ${ }^{1}$
}

\begin{abstract}
Tourism is a magnet of a region to realise a developing area. This study aims to clarify the role of the Government in the Development of Yendi Beach Tourist Attraction in Biak Numfor Regency. This research uses a descriptive qualitative approach. Data collection techniques are done through observation, interviews, literature studies, and documentation. The results showed that the role of the Tourism Office in developing Yendi Beach's tourism potential in Biak Numfor District was dominant as a Motivator compared to other roles, namely as a Facilitator and a Dynamicsator. This role as a facilitator is seen mainly in the form of: provision of facilities and infrastructure for tourist attraction objects, which are still largely borne by the Department of Tourism as the leading sector, facilitation in channelling stimulant financial assistance for people who want to develop tourism attractions, promotion of attraction objects tourism, as well as facilitation to third parties, such as investors and tourism entrepreneurs to develop Yendi Beach tourism business in Biak Numfor Regency.
\end{abstract}

Keywords: Role of Government; Tourism Attraction Data Objects; Yendi Beach.

\section{INTRODUCTION}

Tourism according to Law Number 10 of 2009 is everything related to tourism including business, tourist attractions and attractions as well as businesses related to tourism management. The definition includes all activities related to travel, before and during the trip and returning to the place of origin of the tourist attraction or tourist attractions (natural scenery, recreational parks, historical relics, cultural art performance). Tourism businesses and facilities in the form of service businesses, travel agencies, tour guides, business facilities, accommodation and other businesses related to tourism (Said, Akib, Salam, \& Baharuddin, 2017; Said, Wahidiyat, Andayani, Harifuddin, \& Salam, 2017; Samad, Salim, Arfin, \& Akib, 2018).

Biak Numfor Regency is located in Cenderawasih Bay at the point of $0^{\circ} 21^{\prime}-1^{\circ} 31$ 'S, $134^{\circ} 47^{\prime}-136^{\circ} 48^{\prime} \mathrm{E}$ with an altitude of $0-1,000$ meters above sea level. This district is a group of islands located in the northern mainland of Papua and directly opposite the Pacific Ocean. This position makes Biak Numfor Regency one of the strategic and important places to connect with the outside world, especially countries in the Pacific region, Australia and the Philippines. This geographical location is proof that its position is very strategic to develop industrial areas including the tourism industry.

Talking about tourism located in eastern Indonesia, Papua is the most attractive region because it has extraordinary natural potential. One of the data objects of the tourist attraction is Yendi Beach, located in Yendidori Village, Yendidori District, Biak Numfor Regency. Its 
uniqueness and beauty become valuable capital to advance the tourism sector in Biak Numfor. Advanced tourism development will not be successful without the support of all parties (Babu, Kaur, \& Rajendran, 2018; El-Gohary, 2016; Ndou, Mele, \& Del Vecchio, 2018). Considering that it is still not yet developed, it requires the development of tourist objects as well as involving community participation in the development of a better Yendi Beach Area by focusing on its sustainable aspects.

In developing an area or region into a Tourism Destination, it must be supported by adequate Human Resources both in quality and quantity. Human Resources is recognised as a very important component of tourism development (Hales \& Jennings, 2017). Also, the role of government is needed to motivate or encourage the community to participate in developing tourism in these locations. The goal of tourism development is basically to improve the status of tourism from the development sub-sector to the mainstay development sector that can activate the economy and other related sectors. As a service industry, tourism is expected to function as an agent in development (Babu et al., 2018).

Battor, Ismail, \& Battor (2011) suggest that planning the development and marketing of a tourist destination requires the cooperation and coordination of various government officials, physical planners, architects, financial analysts, investors, economists, sociologists, archaeologists and related elements in it. The role of the government is very necessary for making regulations, conducting supervision, making policies, because the policy is long-term planning that needs to be done by the Government of Biak Numfor Regency especially Yedindori Village in developing tourism in the tourist attraction object of Yendi Beach. Besides the role of the government in preparing human resources, because Human Resources (HR) is one of the supporting factors of the government in developing a tourism destination.

In supporting the development of this tourism destination, the Government of Biak Numfor Regency is expected to be able to provide several facilities, as explained in the Regional Regulation of Biak Numfor Regency Number 3 of 2011 concerning tourism, which in article 38 states that the tourism facilities owned by the region consist of accommodation business facilities, recreation businesses and entertainment, tourist attractions, marine tourism, tourism training and tourism information services. Therefore, supporting facilities are expected to be available so that tourists are interested in visiting tourism, due to the lack of tourism in Papua. Especially in Biak Numfor Regency when compared to other regions, although the bargaining value of tourism is so tempting, to travel to Papua is still considered expensive, both financially and physically. Researchers' observations on the object under study show that, the development in the management of attractions in the Yendidori village has not been maximised so that it gives a great influence also to the community where the community's concern in the Yendidori village in developing data objects Attraction is not optimal and allowing the tourism object neglected so that the interest of tourists to visit this attraction is reduced because nothing is interesting.

Lack of community care in developing this tourism object such as by leaving the facilities in the tourist attraction damaged, not cleaning the tourist attraction environment, lack of good communication access, lack of adequate transportation, and good lodging so that tourists feel uncomfortable. Whereas for the lack of interest of tourists to visit tourist attractions due to uninteresting is whereas we know that there are now so many tourists visiting tourist destinations to take pictures but if the attractions themselves are not attractive such as lack of photo spots, lack of exploration tourist attraction by not promoting the attraction to social 
media. From this background, researchers are interested in researching Tourism Objects by raising the title "The Role of the Government in the Development of Yendi Beach Tourism Destinations in Biak Numfor Regency."

\section{METHOD}

This research is located in Yendi Beach, Kampung Yendidori, Yendidori District, Biak Numfor Regency. This research uses a descriptive-qualitative approach with case study research combined with triangulation techniques. The research data collection was conducted through Observations, Interviews, and Literature Studies. Data analysis is the activity of processing data that has been collected from the field or library to become a set of results, both in discovery and in the data processing. To analyse the data, the researcher uses the logic of deduction, by comparing the theory behind the problem (Creswell \& Poth, 2018). Data obtained from the field is processed by collecting all data to be grouped, selected and then analysed.

The method used in qualitative data analysis is to analyse data based on the quality of the data used to solve the main problem of research, then described in the form of descriptive language. The data analysis technique used is to follow the steps of the "interactive model" (Miles, Huberman, \& Saldana, 2014), namely Data Collection, Data Display, Data Condensation, and Conclusion Drawing / verifying.

\section{RESULT AND DISCUSSION}

The purpose of developing each of the existing tourist destinations, especially the Yendi Beach Tourism Object, Biak Numfor Regency, provides benefits or benefits to the government, tourists, and especially the residents or the local community. With the development carried out it provides enormous benefits, especially the local community through the economic improvement they get.

Yendi Beach Tourism Potential Development has made tourism potential able to contribute to increasing the amount of local revenue. This is due to the development of tourism potential, in this case Yendi Beach, then automatically administrative services, infrastructure, and typical tourism products can be improved to attract visitors/tourists to visit these attractions. With the development efforts mentioned above, it is in line with expectations, namely an increase in the number of tourist visits that have an impact on ticket sales (retribution) which can ultimately contribute to an increase in the amount of Original Local Revenue. In the concept of development, the role of government determines the success of tourism development by moving the "local economy wheel" of the area. Micro, Small and Medium Enterprises (MSMEs) are also growing so that the empowerment of local communities has a positive impact on the level of participation in development. The concept of developing Yendi Beach which is a comfortable tourist spot with all the services, beauty and souvenirs offered will directly impact on the increase of local revenue significantly.

Not only that, but the role of the government can also determine the direction and participation of the people who live around the area of tourist attractions and include all of the various customs and cultures in Kampung Yedindori Biak Numfor Regency to increase public awareness of respect for the culture and local natural preservation. If the local government does this continues to be improved, it is not impossible that the area around Yendi Beach can become a developing and independent tourism area. Therefore, to see the extent of the role of the 
government in the development of Yendi Beach attractions, the concept of the government offered by researchers tries to describe the role of government based on the theory put forward by experts, namely the role of the government as a motivator, facilitator, and dynamist in developing tourist destinations.

Government as Motivator. The government can create enthusiasm or spirit to encourage the achievement of rapid economic growth and requires not only the development of supply factors which increase the production capacity of the people, namely human and natural resources, capital and technology, but also external demand factors, without increasing potential can be realised. To that end, the local government is constantly making changes and creating a breakthrough in how to create jobs so that they can overcome or reduce the unemployment rate and at the same time have implications for improving social welfare, especially those living in Kampung Yedindori Biak Numfor Regency.

The application of the concept of the role of government as a motivator is very important to be realised by the local government in increasing community motivation so that it can affect the level of public awareness to love the existing tourism development areas. The role of the local government is very important, both in developing Yendi Beach attractions and involving the community, as well as the role of the local government in motivating all levels of government to be more active in developing existing tourism products.

Government as Motivator. The government can create enthusiasm or spirit to encourage the achievement of rapid economic growth and requires not only the development of supply factors which increase the production capacity of the people, namely human and natural resources, capital and technology, but also external demand factors, without increasing potential can be realised. To that end, the local government is constantly making changes and creating a breakthrough in how to create jobs so that they can overcome or reduce the unemployment rate and at the same time have implications for improving social welfare, especially those living in Kampung Yedindori Biak Numfor Regency.

The application of the concept of the role of the government as a motivator is very important to be realised by the local government in increasing community motivation so that it can influence the level of public awareness to love the existing tourism development areas. The role of the local government is very important, both in developing Yendi Beach attractions and involving the community, as well as the role of the local government in motivating all levels of government to be more active in developing existing tourism products.

The development of the tourism sector was successful because the wider community could play an active role. So that the wider community can play a role in tourism development, the community is given an understanding of what is meant by tourism, the benefits and benefits gained from these creative economic activities. Besides, the community also knows things that can be detrimentally caused by the community. Therefore, the role of the local government as a motivator is very important in improving the tourism object of Yendi Beach. Likewise, the involvement or involvement of citizens in creative economic activities will determine the success of the development of attractions. The impact is that it can reduce the economic, social and cultural gaps of the community by being motivated to maintain the environmental attraction of the tourist attraction.

According to the expert, quoted in the Journal of the Contribution of Tourism to Economic Growth and Food Security (tourism's contribution to economic growth and food security) the economic benefits of tourism are not only in direct economic growth but in the 
process by which tourism can expand employment opportunities for the poor in these areas, increased access to services and supporting infrastructure and mitigation of environmental and natural resource impacts (Richardson, 2010). These benefits have been accompanied by negative impacts such as the transmission of disease outbreaks, the threat of terrorism and also leakage of income from the tourism sector when greater tourism investment is dominated by foreign ownership, employment of foreign citizens and imported foodstuffs (Richardson, 2010, p. 54).

The tourism sector is one of the sectors that can contribute to the economy in Biak Numfor Regency, in this case the development of Yendi Beach tourist attraction day in Yendidori Village because it can absorb labour. This happens because of the demand for hotels, restaurants and supporting services for the transportation of tourists who come. With the arrival of tourists to Yendi Beach, it opens up opportunities for people to become entrepreneurs or managers of hotels, restaurants, transportation services and management of tourist attraction objects. Thus providing opportunities for residents to work, and get income later. Therefore, the role of the government as a motivator is very clear and important in determining the development of attractions.

The government as a motivator in developing tourism tries as much as possible to further improve and motivate the community through training to achieve the desired goals. The results of observations in the field of researchers see that the motivation of the community in developing tourism objects is very high but is hampered because HR is still lacking in tourism knowledge, besides that the government has not been maximally involved in motivating the Yendi Beach community of Yedindori Village.

The government's efforts as a motivator in motivating by providing training and education to the community in this case the Yendi Beach tourist attraction manager has not been optimal, this shows that the quality of existing human resources has not been able to implement a good tourist management process so tourism marketing is constrained because the community does not yet have skills in developing existing attractions. Especially the performance of tour managers because they are the first people encountered by tourists. The manager of the tourist attraction has a very important role because during the holidays more tourists intersect or adapt to the manager and tour guide. The role of a tour guide largely determines good or bad the impression received by tourists.

Government as a Facilitator. Government as a Facilitator. The role of the local government as a facilitator is to accelerate development through improving the environment and the behaviour of residents. This role can include streamlining the development process, improving planning procedures and establishing local regulations. Pitana \& Gayatri (2005) suggested that local government has a role in developing the potential of regional tourism as a facilitator. As a facilitator for the development of tourism potential, the role of the government is to provide all the facilities that support all programs held by the Department of Tourism. In practice, the government can collaborate with various parties, both private and public. Therefore, in the study analysed items that become a reference to get the results used in developing Yendi Beach attractions, namely: promotion of attractions, supporting facilities and infrastructure, as well as supporting budget availability.

Government as a dynamic. The role of the dynamics is the effort of the Tourism Office of Biak Numfor Regency to realise good tourism governance. Therefore, the results of this study outline problem related to the role of the government as a dynamic, namely conducting good 
$194 \mid$ Jurnal Administrare: Jurnal Pemikiran Ilmiah dan Pendidikan Administrasi Perkantoran

Volume 6 Number 2 July- December 2019. Pages 189-198

cooperation between the government and the private sector and the community, partnerships with outside parties, and community participation.

The role of the regional government in this case the responsible tourism office in the field of tourism will largely determine the development of tourism in the Biak Numfor Regency going forward. Cooperation and involvement of the private sector and the community in the field of tourism are facilitated by the government in this case the Tourism Office of Biak Numfor Regency because it is certain that the Office cannot walk alone and work alone to develop tourism in Biak Numfor Regency without the intervention of existing stakeholders, namely the private sector and the community. Tourism activities are systemic and their implementation cannot be carried out separately, so inevitably there must be synergy between existing stakeholders.

Public and private involvement is also very important in the preparation of regulations in the context of this region is the Regional Regulation of Biak Numfor Regency. Public and private involvement in planning and drafting local regulations is still minimal because they are more involved in the implementation phase, although it is recognized that tourism or private actors and the community are the objects of the policies made. The relationship of the Biak Numfor Regency Tourism Office with all the stakeholders, both public and private, is generally said to be not good enough, because it turns out that the Biak Numfor Regency Tourism Office has not been able to embrace all stakeholders to be able to actively participate in the development of tourism in their area, especially in terms of policymaking. The cooperation developed between the government is very good at increasing the rate of development of Yendi Beach tourist attraction. Therefore, it is understood that the important role of the government is to encourage increased participation of the people of Yedindori Village to increase the number of tourists from outside the region and from foreign countries. According to Pitana \& Gayatri (2005: 95) that local government has a role in developing the potential of regional tourism as a dynamic, in the pillars of the principles of good governance so that that ideal development can take place, the government, private sector and the community work well together. The local government as one of the stakeholders in tourism development has a role in synergising the three parties, so that among them a mutual symbiosis is created for the development of tourism.

The principle of good governance is an idea and value to regulate the pattern of relationships between government, the private sector and the community. The partnership between the regional government and the private sector is a common step taken to cover the limitations of the regional government in providing public services and regional development. The partnership builds relationships between all levels of government and civil society to improve good governance in Indonesia sustainably. The partnership carried out in this case is the cooperation that has been or is being carried out with other parties that are useful to provide convenience in the process of implementation (operationalisation) of the formation of community-based tourism.

Partnerships are very important in developing tourism for attracting tourists from outside, especially the role of the government in conducting various cooperation programs between the private sector and the community. The results of observations in the field found that partnerships built by the government, the private sector and the community were not optimal, where in this case the government lacked the socialisation of tourism in Yendi Beach. This finding is by the opinion of Rorah (2012) regarding "Community Based Tourism in the Village of Kebonagung, Imogiri District". This study revealed that the Management of Kebonagung 
Village was carried out directly by the local community through tourism awareness groups. This group is an organisation formed and its members are the people of Kebonagung Village. Kebonagung Tourism Village as a form of community-based tourism has implemented three principles of community-based tourism although it has not been implemented maximally. Relevance with the results of this study is the similarity of objectives, namely knowing the development of community-based tourism in a region and the role of community participation in the development of the tourism sector.

Community participation is the awareness and desire of the community to contribute to any government activity that invites community participation as citizens. To optimise the role of the government, community participation needs to be the main focus, because the community is the subject and object of the policy. The participation of the Yedindori village community about the development of the Yendi Beach tourism object is very high, but is constrained from the government side in providing direction and motivation to manage the tourist attraction as initial capital for community income and regional income. The role of the Office as the Regional Government responsible for the tourism sector will determine the development of tourism destinations in the Biak Numfor Regency in the future. Cooperation and involvement of the private sector and the community in the field of tourism need to be facilitated by the government in this case the Tourism Office in Biak Numfor Regency, but in reality the tourism office cannot walk alone and work alone to develop Tourism in Biak Numfor Regency without the intervention of existing stakeholders namely private and public.

Based on the results of research and discussion above, it can be stated that the Role of the Office of Tourism in the Development of Tourism is an effort made by the Office about the authority it has to develop tourism in its region, which includes efforts to provide tourism support facilities (Facilitators), cooperation which is synergistic with various tourism stakeholders (dynamic), and is a driving force for local communities to always support the development of tourism in their regions (motivators).

\section{CONCLUSION}

The role of the Tourism Office in the Development of Yendi Beach Tourism Potential in Biak Numfor Regency is dominant as a Motivator compared to other roles, namely as a Facilitator and a Dynamicsator. This role as a facilitator is seen mainly in the provision of object infrastructure which is still largely borne by the Dinas, the distribution of stimulant funds for people who want to develop a tourist attraction, promotion of tourist attraction objects, and facilities provided to third parties such as investors and tourism entrepreneurs to develop their tourism business.

The role of the local government as a facilitator is the Tourism Office to make it happen by providing infrastructure facilities in tourism objects, providing facilities to investors and tourism entrepreneurs in the form of policies and regulations that can protect and benefit tourism investors and entrepreneurs, marketing tourist attraction objects, facilitating groups people aware of tourism to get stimulant funds and so forth. As a Motivator, its role is needed to motivate the community, investors and tourism entrepreneurs, both in the form of socialisation and training and the provision of stimulant funds. Motivation is also given to investors and tourism entrepreneurs so that investors and tourism entrepreneurs are interested in developing Yendi Beach tourism businesses, as well as indirectly alleviating the budget burden from the 
196 Jurnal Administrare: Jurnal Pemikiran Ilmiah dan Pendidikan Administrasi Perkantoran
Volume 6 Number 2 July- December 2019. Pages 189-198

Tourism Office to develop tourism potential in Biak Numfor Regency. As a dynamic, the regional government does various things related to cooperation between sectors, both the private sector and other government sectors, as well as with the local community

\section{REFERENCES}

Babu, D. E., Kaur, A., \& Rajendran, C. (2018). Sustainability practices in tourism supply chain: Importance performance analysis. Benchmarking: An International Journal, 25(4), 11481170. https://doi.org/10.1108/BIJ-06-2016-0084

Battour, M., Ismail, M. N., \& Battor, M. (2011). The impact of destination attributes on Muslim tourist's choice. International Journal of Tourism Research, 13(6), 527-540.

Creswell, J. W., \& Poth, C. N. (2018). Qualitative inquiry Research Design Choosing Among Five Approaches (Vol. 53). https://doi.org/10.1017/CBO9781107415324.004

El-Gohary, H. (2016). Halal tourism, is it really Halal? Tourism Management Perspectives, 19, 124-130. https://doi.org/https://doi.org/10.1016/j.tmp.2015.12.013

Hales, R., \& Jennings, G. (2017). Transformation for sustainability: The role of complexity in tourism students' understanding of sustainable tourism. Journal of Hospitality, Leisure, Sport \& Tourism Education, 21, 185-194. https://doi.org/https://doi.org/10.1016/j.jhlste.2017.08.001

Kumorotomo, W., \& Purwanto, E. A. (2005). Anggaran berbasis kinerja: konsep dan aplikasinya. Diterbitkan oleh Magister Administrasi Publik Universitas Gadjah Mada ....

Miles, M. ., Huberman, A. ., \& Saldana, J. (2014). Qualitative Data Analysis, A Methods Sourcebook (3rd ed.; Tjetjep Rohindi Rohidi, ed.). Jakarta: UI-Press.

Ndou, V., Mele, G., \& Del Vecchio, P. (2018). Entrepreneurship education in tourism: An investigation among European Universities. Journal of Hospitality, Leisure, Sport \& Tourism Education. https://doi.org/https://doi.org/10.1016/j.jhlste.2018.10.003

Pendit, N. S. (1986). Ilmu pariwisata: sebuah pengantar perdana. Pradnya Paramita.

Pitana, I. G., \& Gayatri, P. G. (2005). Sosiologi Pariwisata: Kajian sosiologis terhadap struktur, sistem, dan dampak-dampak pariwisata. Andi.

Richardson, R. B. (2010). The contribution of tourism to economic growth and food security.

Rorah, D. N. P. (2012). Pengelolaan Pariwisata Berbasis Masyarakat (Community Based Tourism) Di Desa Wisata Kebon Agung, Kecamatan Imogiri. Skripsi. Universitas Negeri Yogyakarta.

Said, F., Akib, H., Salam, R., \& Baharuddin, A. (2017). An Analysis of Tourism Visit Trend. 2nd International Conference on Education, Science, and Technology (ICEST 2017). Atlantis Press.

Said, F., Wahidiyat, A., Andayani, D. D., Harifuddin, H., \& Salam, R. (2017). Development of 
Travel Attractions Through the Design of Google SketchUp Based Coastal Tourist Map (Pengembangan Daya Tarik Wisata Melalui Perancangan Peta Wisata Pantai Berbasis Google SketchUp). Pekommas, 2(2).

Samad, Y., Salim, M., Arfin, M., \& Akib, H. (2018). The Functions of Language in Realizing the Indonesian Culinary on the official tourism website of Indonesia: A Tourism Discourse Perspective. The Functions of Language in Realizing the Indonesian Culinary on the Official Tourism Website of Indonesia: A Tourism Discourse Perspective (October 31, 2018). Ewha Journal of Social Sciences, Forthcoming.

Siagian, S. P. (1992). Dasar-Dasar Manajemen. Bandung: Alfabeta. 
198 Jurnal Administrare: Jurnal Pemikiran Ilmiah dan Pendidikan Administrasi Perkantoran Volume 6 Number 2 July- December 2019. Pages 189-198 